\title{
Not Featherbedding, but Feathering the Nest: Human Resource Management and Investments in Information Technology
}

\begin{abstract}
ADAM SETH LITWIN ${ }^{1}$
This study draws on employment relations and management theory, claiming that certain innovative employment practices and work structures pave the way for organizational innovation, namely investments in information technology (IT). It then finds support for the theory in a cross-section of UK workplaces. The findings suggest that firms slow to adopt IT realize that their conventional employment model hinders their ability to make optimal use of new technologies. Therefore, the paper advances the literature beyond studies of unionization's impact on business investment to a broader set of issues on the employment relations features that make organizations ripe for innovation.
\end{abstract}

Introduction

ECONOMICS AND MANAGEMENT RESEARCH HAS DEMONSTRATED THAT THE PRODUCTIVITY impact of investments in information technology (IT) rests on a well- developed set of employment practices falling under the umbrella of human resource management (HRM). As a result, even those outside the human resources (HR) or employment relations domains now accept that the "information age" is characterized as much by workers and employment practices as it is by hardware and software (Brynjolfsson and Saunders 2010). That raises a key question: To what extent might some organizations be better positioned than others to benefit from IT investment? More specifically, do certain features of the employment relationship drive the IT investment decision?

This question is not as novel for scholars of work and employment as it may first appear. Technology has long been at the core of pluralist industrial relations theory and research. Slichter and his colleagues (e.g., Slichter 1941; Slichter, Healy, and Livernash 1960) examined the determinants of union policies toward technological change. They argued that union responses ranged from outright opposition to "willing acceptance" or even encouragement, depending on the degree to which the union could ensure workers a share of the resulting gains or at least adequate employment protections - through what the Webbs labeled "productivity bargaining" (1897) more than a half century earlier.

Among the most well-known and odious paths by which unions leveraged their collective power to spread the costs and benefits of technological change was "featherbedding" - the practice of forcing management to agree to hire more workers than were actually necessary to do the job. The eponymous case involved the continued employment of railroad firemen on locomotives, long after the industry had transitioned from wood- or coal-fired steam power to diesel power. As diesel locomotives required no fire, management claimed that firemen could literally spend their shift reclining on the feathered mattresses intended for paying passengers on sleeping cars (Murray 1998). However, from a labor economist's perspective, employment relations structures and processes were simply spreading the cost associated with technological change by constraining the degree to and the speed with which capital-labor ratios could be adjusted (Farber 1986; Simler 1962; Weinstein 1964). Although technically outlawed in the United States as part of the 1947

1 The author's affiliation is Carey Business School at Johns Hopkins University, Baltimore, MD and Employment Policy Research Network. Email: aslitwin@jhu.edu. He acknowledges the UK Department of Trade and Industry; the Economic and Social Research Council; the Advisory, Conciliation and Arbitration Service; and the Policy Studies Institute as the originators of the 2004 Workplace Employment Relations Survey data, and the Data Archive at the University of Essex as the distributor of the data. The National Centre for Social Research was commissioned to conduct the survey fieldwork on behalf of the sponsors. None of these organizations bears any responsibility for the analysis and interpretations of the data. John Forth, in particular, has been extremely helpful in shedding light on the intricacies of these data. The author would also like to thank Ariel C. Avgar, Alex Bryson, and Jody Hoffer Gittell, as well as seminar participants at the University of Illinois at Urbana-Champaign and the 2011 annual meeting of the Labor and Employment Relations Association for their constructive feedback. 
Taft-Hartley revisions to the National Labor Relations Act (Budd 2010), the idea that collective bargaining might somehow stymie business investment remained a topic of interest to researchers, particularly as unions became an increasingly influential force through the early 1980s. Whether or not the net effect of unions was to dampen investment and innovation had powerful policy and managerial implications. It would determine the extent to which employment relations was a cause for structural changes in the economy, namely a slowdown in long-run growth, as well as cyclical changes like stagnating wages and high unemployment.

Although research in employment relations has now transcended collective bargaining to include a broader array of employmentrelated phenomena, the field has yet to revisit this issue. In particular, it has yet to explicitly examine how innovative employment practices and work structures might drive innovation or, in particular, IT investment, despite the need for such analysis. To the extent that innovation remains a central force for economic growth, managers' reluctance toward modernizing their approach to managing people could actually have negative macroeconomic implications. In this sense, employment relations emerges as an economic policy lever. Closer to ground level, even for those managers that are themselves inclined toward HRM, the large, upfront cost associated with its implementation will demand that managers justify new employment practices and work structures to their superiors and to shareholders. Therefore, the time has come for researchers to explicitly consider the ways that HRM influences IT investment.

This paper begins to fill this gap. It does so by analyzing data from the Workplace Employment Relations Survey 2004 (WERS2004) (Department of Trade and Industry 2005), a cross-section of UK workplaces. It begins by theorizing the ways that employment practices and work structures should drive IT investment, identifying features of the employment relationship that received research suggests complement investments in IT, namely the incidence of so-called high-performance work practices (HPWPs) and the degree to which frontline staff are provided discretion and autonomy to do their work. These same characteristics of the employment relationship are then shown to be strongly correlated with whether or not a workplace has introduced or upgraded computers in the previous 2 years, results that are robust to a technique that enables other organizational and workforce characteristics to instrument for the HRM variables. These findings reveal that employment relations structures and processes, once viewed as a likely deterrent to investment and innovation, can actually prime an establishment for technological change. That is, innovative employment practices and work structures can actually "feather the nest," preparing the firm for the potentially massive impact that new technologies are likely to have on production and workflows. The paper concludes with a discussion of the significance of these results for understanding the ways that employment relations constructs-HRM in particular- "pave the way" for investments in new technologies, an area that employment relations scholars have yet to tackle.

\section{IT-Enabling Employment Practices and Work Structures}

Before testing for a link between HRM and IT investment, one must define these terms and establish a conceptual foundation for their association. As Kaufman (2004) points out, a significant obstacle to the development of theory around HRM has been its lack of a stable, agreed-upon definition. Some authors use it to describe "the science and the practice that deals with the nature of the employment relationship and all of the decisions, actions, and issues that relate to that relationship" (Ferris et al. 1995: 1-2), whereas others instead suggest it is one particular approach - the "high-road" one in which workers are construed as organizational assets rather than as costs to be minimized (e.g., Kochan and Osterman 1994; Storey 2007). Given that we are building upon employment relations theory, the most useful definition of HRM would be one that encompasses all aspects of the employment relationship, including but not limited to the incidence of innovative employment practices such as teamwork and cross-training as well as the use of novel work structures in which autonomy and decision making are devolved downward from management ranks and closer to the frontlines.

With respect to IT, the best way to define it would be to name the specific technology under study, for example, mainframes, 
distributed networks, or web 2.0 applications, as each specific manifestation of IT no doubt evokes different theoretical implications. Unfortunately, large-n, cross-industry studies preclude such a precise definition. Consequently, this study follows Brynjolfs- son, Hitt, and Yang's (2002) lead, applying the IT label to computer technology such as central processors, personal computers, and peripherals, conceding that such a broad definition assuredly masks variation in the types of technologies deployed, how exactly the technology gets integrated into work structures, and the contested nature of the "negotiation" that ultimately gives birth to the IT decision (Badham 2005; Noble 1984).

Having defined HRM and IT, we can now turn to the theory that links them. An important path by which employment practices influence economic performance is through their ability to help organizations squeeze larger performance gains from new hardware, software, and peripherals-IT. The work of Brynjolfsson et al. (e.g., Bresnahan, Brynjolfsson, and Hitt 2000, 2002; Brynjolfsson, Hitt, and Yang 2002) cements these "complementarities" in cross-industry, national estimates of production functions, results that also find strong support in mixed-method, industry- and firm-focused studies in both the manufacturing (e.g., Bartel, Ichniowski, and Shaw 2007; Kelley 1996) and service sectors (e.g., Batt 1999; Litwin 2011). The upshot is that incumbent employment practices grew around or perhaps were deployed strategically around the incumbent technology. Therefore, it should not be surprising that the preservation of these practices would dampen the returns to new IT investments.

This leaves at least two important questions. First, why would scholars of work and employment care about HRM as a driver of IT investment? Second, which aspects of HRM does theory suggest should facilitate IT adoption? As alluded to earlier, technology has long played a key role in studies of the employment relationship. The Webbs (1897) and Slichter et al. (e.g., Slichter 1941; Slichter, Healy, and Livernash 1960) explored trade union responses to the threat of technological change. When coupled with Dunlop's ([1958] 1993) establishment of the "technological" context as a key driver of industrial relations outcomes, it makes sense that a subsequent generation of work and employment scholars - those focused on union correlates with "real" outcomes and motivated by Freeman and Medoff's (1984) analysis of unions, employed a newly emerging econometric toolkit to examine the relationship between collective bargaining and business investment (e.g., Addison et al. 2007; Bronars, Deere, and Tracy 1994; Hirsch 1992). That literature theorizes that unions encourage investment through "collective voice" and by constructively channeling worker discontent. On the other hand, managers of unionized firms could be ex ante less apt to sink large amounts of capital into new machinery or technology, knowing that ex post, unions could demand a larger share of quasi-rents than agreed upon upfront (Grout 1984).

To be sure, collective bargaining and HRM are not opposite sides of the same theoretical coin. Management is generally confronted with an organized workforce and collective bargaining, and then within that context, must make a series of decisions regarding HR and business strategies (Kochan, Katz, and McKersie 1986). On the other hand, managers themselves make active decisions regarding whether or not to modernize employment practices and how they want work structured. For example, do they want employees to work in teams? To what extent would they like workers to be interchangeable, in the sense that they could serve as "utility players" in the production or service process? Would managers like planning completely separated from execution, as prescribed by Taylor (Kanigel 1997), or do they instead want to allow and encourage frontline workers to make key decisions on their own?

Although collective bargaining and HRM are very distinct constructs, employment relations nonetheless offers a useful framework for viewing management decision making in the context of myriad types of market and institutional constraints. In strategic choice theory (Kochan, Katz, and McKersie 1986), unionization is framed as a (management) choice variable, at least in the sense that management can accept unionization or fight it vociferously. The upshot is that management's acceptance of unionization takes the firm down one branch of the decision tree, with its subsequent strategic options, and management's successful defeat of unionization paves the way for a completely separate set of subsequent options. Therefore, while collective bargaining and HRM should not be 
viewed as parallels in a theory linking employment relations structures and processes with a firm's investment behavior, many of the features of unionism that have been theorized to encourage or retard investment can be drawn on to better understand how HRM should influence investment decisions around new technologies.

Against this backdrop, just as unions can spur or hamper economic progress through their impact on investment, other employment relations structures and processes can be theorized to influence the nature and pace of technological change. Yet, outside the context of collective bargaining, work and employment scholars have yet to carefully examine the ways that HRM influences technology investment. That is, aside from unionism, are there characteristics of an organization's employment model that make the firm especially ripe or especially reluctant to adopt IT? One approach would be to consider in broad terms how features that inhere in a unionized employment relationship might translate into ones characterized by HRM.

There are number of avenues by which theory suggests trade unions could influence investments in new technologies, and one can imagine some of these same phenomena playing out in an environment characterized by HRM, be it union or nonunion. For example, as noted above, Freeman (1976) and later Freeman and Medoff (1984) argued that the structured grievance procedures typically associated with unionization facilitate the constructive channeling of worker discontent. To the extent HRM succeeds in creating a similar set of intra-organizational institutions for resolving workplace disputes and collecting feedback, it, too, should see these enhanced returns from IT investment. On the other hand, one could also consider the ways that unions are theorized to attenuate capital investment, either by increasing costs or by reducing marginal returns. On the cost side, Denny and Nickell (1992) suggest that unions facilitate worker resistance to new technologies, effectively adding to the cost of installation. In fact, it has been demonstrated empirically that the mere expectation of union resistance to technological change could deter firms from making these investments, before unions even have an opportunity to effectuate this response (Willman 1986). Consequently, to the extent HRM can be used to facilitate technological change or that managers believe HRM can be applied prospectively to mitigate worker resistance to new technologies, the incidence of HRM should be positively associated with IT investment.

Likewise, even in an employment relations framework that long ago proscribed explicit featherbedding, unions can maintain inflexible work rules. This practice, famously associated with the longshoring industry, deters investment by effectively reducing the marginal product that that technology can generate (Farber 1986). To the extent that HRM succeeds in delivering promises of flexibility (e.g., Becker and Huselid 1998), identical technology could be expected to deliver more in a setting characterized by HRM than in an otherwise identical environment characterized by a more conventional employment model. In the net, many of the hypotheses describing the relationship between unions and investment can be bundled into a story about means and variances (Latreille 1992): assuming away the counterarguments relating to beneficial union voice effects, unions appear to reduce the mean and to increase the variance in the expected returns to investments in new technologies. On the contrary, the enlightened approach to HR characterized by HRM may succeed in increasing the likely returns to these investments as well as the degree of certainty surrounding their ability to benefit the organization. Indeed, prior research suggests at least two paths by which HRM could be instrumental in boosting managers' expectations and certainty about returns to investments in IT-the incidence of HPWPs such as team-based production, cross-training, and employee involvement in problem solving, and the degree of decentralization of authority and discretion afforded the frontline workforce.

The aforementioned "strategic choice" framework (Kochan, McKersie, and Cappelli 1984), posited to explain the ways that the employment relations climate shapes managerial decision making, offers a useful approach for thinking about the HRM determinants of IT investment. In the original framework, an exogenous intensification of product market competition prompts a cascade of managerial decisions-whether or not to stay in the market, the business strategy if the firm does stay in the market, and the requisite 
employment arrangements, "high-road" or "low road," that would serve that chosen strategy, all influenced by the market, technological, and relative power contexts. With respect to IT investment, the strategic choice approach is initiated by exogenous declines in the price of IT (Bresnahan, Brynjolfsson, and Hitt 2002; Mil-grom and Roberts 1990). The construct modeled in this study is whether or not to make the IT investment, influenced by the firm's employment model. In particular, does the organization have in place the employment practices and work structures that make such investments especially likely to improve performance?

High-Performance Work Practices. Evidence suggests that the optimal use of IT requires a nontraditional set of employment practices (Batt 1999; Bresnahan, Brynjolfsson, and Hitt 2002; Litwin 2011). Most often included in the list of HPWPs are teamwork, cross-training, and employee involvement in problem solving (Cappelli and Neumark 2001; Ichniowski et al. 1996). These practices prove difficult to isolate conceptually, as cross-training and problem solving are more likely to happen within the scope of team-based production - the HR "bundles" theory put forth by MacDuffie (1995). In his analysis of the world auto industry, he suggests that developing necessary skills for problem solving requires cross-training. Moreover, in his sample, problem solving specifically includes the task of improving equipment performance over time by finding new ways to employ production technologies. Others have argued that group-based employee involvement mechanisms can tap workers' tacit knowledge for informal shortcuts and other modern versions of what were once called "jigs," and that these structures complement IT's positive impact on plant performance (Kelley 1996). Batt (1999) also found similar economic benefits arising from the combined effects of IT and teamwork, even in a sales environment.

There are two studies that come close to doing what this one does - predict- ing IT investment as a function of HR practices. Bartel, Ichniowski, and Shaw (2007) briefly examine the employment practices-IT link explicitly as a small part of their extensive examination of the ways human and technological capital complement one another in the production of valves. They estimate probit regressions to show that investments in different technologies-including computer numerically controlled machinery and three-dimensional computer-aided design are positively associated with a plant's instating of teams, employee involvement structures, and training. They also note that these HR practices frequently appear to pre-date IT adoption. Likewise, in work that precedes their production function estimates, Hitt and Brynjolfsson (1997) show that firms that are extensive users of IT tend to adopt team-based production systems and to install employee involvement groups. They argue that both teams and employee involvement support a much more expansive organizational change, a trend toward the devolution of authority to the frontlines.

Decentralization. As noted earlier, scholars have argued that the optimal use of IT requires workers be given more autonomy or discretion in how they do their work. This is rooted in economic and organization theory. The idea is that IT reduces the cost of transmitting or communicating information. Accordingly, the theory of "bounded rationality" (Simon 1951, 1973) implies that without a reallocation of decision rights, the glut of newly available information would overwhelm top management, preventing them from making full use of most of it. Furthermore, this same IT facilitates the sorting and disseminating of job-relevant information to those on the frontlines. Provided these workers have the necessary autonomy to process the information and to make decisions based on it, that is, that decision rights and information are "co-located" within the organization (Jensen and Meckling 1995), IT can boost performance by making these workers more productive. The deployment of IT without a commitment to decentralization, at minimum, blunts the effectiveness of the new technology, although the new onslaught of "information overload" could potentially create a negative relationship between IT and performance.

There is empirical support for this decentralization theory. Hunter and Laf- kas (2003) find that coupling IT with new forms of work organization that allow for autonomy-both of individuals and of teams-is associated with higher wages, one proxy for worker productivity. Likewise, the cross-industry econometric analyses mentioned earlier show that IT investment is associated with a larger 
growth in output where firms report decentralized forms of work organization (Bresnahan, Brynjolfsson, and Hitt 2000, 2002). Therefore, firms reporting the incidence of decentralized work structures should be better positioned than others to gain from investments in IT. Consequently, these organizations will be more likely to make these investments in the first place.

Data

This study employs data from the Workplace Employment Relations Survey 2004 to analyze the relationship between HRM and IT investment. The survey was the joint effort of the UK Department of Trade and Industry (DTI); the Economic and Social Research Council (ESRC); the Advisory, Conciliation and Arbitration Service (Acas); and the Policy Studies Institute (PSI). Nearly all of the data come from the Survey of Managers, which mitigates single-response bias by targeting the most informed potential respondent (Huber and Power 1985), using the senior manager responsible for employment relations on a day- to-day basis to act as an "informant of their workplace," where "workplace" refers to the "the activities of a single employer at a single set of premises" (Kersley et al. 2006: 3). Setting the workplace (i.e., the establishment) as the unit of analysis improves the reliability of all subsequent measures and estimates relative to approaches that instead rely on firm- or organization-level data, where there is much more likely to be a disconnect between headquarters and any particular branch as well as uneven realization of corporate-level policies across a firm's many workplaces (Hunter and Pil 1995; Ichniowski et al. 1996). The full sample consists of 2295 responses, representing a universe of about 700,000 workplaces with five or more employees (covering 89 percent of the British labor force). The sample was stratified by workplace size and industry, where larger workplaces and workplaces in certain sectors were given a greater probability of selection. Weights were developed to ensure the final sample was representative of the population from which it was drawn. The survey had a 64 percent response rate, impressive given that it took nearly 2 hours to complete the phone interview (Kersley et al. 2006).

As implied previously, there was one variable relied upon in the study that was not constructed from the responses to the Survey of Managers. The measure of the employment relations climate, to be detailed later, was instead derived from the WERS2004 Survey of Employees. This instrument is a very short, self-completion questionnaire distributed to a random selection of up to 25 employees at those workplaces that participated in the Survey of Managers. While there are number of advantages to using data from multiple employees rather than from a single manager, this was the only variable called on the study that could be constructed identically using either survey instrument, meaning one could directly compare the answers provided by managers to those of their employees. While the data were somewhat positively correlated $(q=0.41)$, the management respondents systematically rated the overall employment relations climate more favorably than did their employees $(t=15.31, p<0.001)$. As this variable is also the single most subjective variable called upon in the study, this raised the concern that so-called "common method bias" could artificially inflate the relationship between the employment relations measure and the dependent variable (Podsakoff et al. 2003). Drawing the independent variable and the dependent variable from separate surveys effectively counters this problem (Litwin 2011). Nonetheless, parallel analyses to those presented in the paper were also conducted using the manager's perceptions of the employment relations climate, yielding qualitatively identical results. In total, 22,451 usable employee surveys were returned, representing a 61 percent response rate.

Dependent Variable. Table 1 defines the variables employed in this study and explains how each is constructed. The dependent variable in the study is the manager's binary response to the question, "Has management introduced or upgraded computers in this workplace in the last 2 years?" where affirmative answers are set to one and the answer "no" is the referent category. Although these data did not offer an alternative, continuous measure of IT investment, the use of a binary one facilitates comparisons between results presented here and earlier work. Recall that Bartel, Ichniowski, and Shaw's (2007) paper on valve manufacturing measured technology investment using binary variables. Likewise, the employment relations literature frequently makes use of binary or at least ordinal measures for the dependent variable in studies of unionization's impact on investment (e.g., Hirsch and Link 1987; Keefe 1991). In 
fact, analyses of trade union impact on investment have used earlier incarnations of this exact same survey item from previous administrations of the same survey (Latreille 1992; Machin and Wadhawni 1991). ${ }^{2}$

Focal Independent Variables. The measure of HPWPs is derived from three survey items meant to capture the incidence of more collaborative and more flexible employment practices-team-working, cross-training, and problem-solving groups. These are among the most commonly cited practices in the high-performance literature (e.g., Cappelli and Neumark 2001; Ichniowski et al. 1996), which is probably why Bartel, Ichniowski, and Shaw (2007) chose them for their study of IT and work practices. For each question, respondents provided the approximate proportion of workers involved in the practice. Those scores were summed and partitioned into HPWP "bins" labeled from 0 to 3, akin to Ichniowski, Shaw, and Prennushi's (1997) technique, where 3 represents the largest value on the HPWP index.

Ideally, the degree of autonomy or decentralization used to describe a given workplace's work structures would be measured as Hunter and Lafkas (2003) do, summing the number of work- and job-specific activities and decisions that workers can perform and make on their own. However, as the present study is not specific to a single role or job title, the questions had to be more global. Respondents rated on a 0-3 scale-0 meaning "none" and 3 meaning "a lot" - the extent which they have discretion over how they do their work, control of the pace at which they do their work, and involvement in how their work is organized. These are then summed and averaged into an autonomy scale $(a=0.71)$ ranging from ranging from 0 to 3.

Control Variables. All multivariate estimates include a linear and quadratic term to control for the number of workers on the payroll at an establishment, typical of studies of investment behavior or of IT (Addison et al. 2007; Machin and Wadhawni 1991), as well as a dummy to capture foreign ownership of the establishment. As this study relies upon establishment-level rather than firm-level data, it also makes sense to control for subsidiary status, as being a single branch of a much larger organization could weaken the causal connection between establishment-level measures and establishment-level adoption (Addison et al. 2007; Latreille 1992). And, given the collective bargaining origins of this research, one must control for union status. In this case, this is done using a binary variable to denote whether or not at least one union in the workplace is recognized for the purposes of bargaining over terms and conditions. While this would prove insufficient for advancing our understanding of the instrumentality of collective bargaining per se on IT investment, it allows us to isolate and control for the mechanism by which unions are theorized to dampen IT investment without picking up potentially union-driven, positive changes in the two, focal independent variables.

Finally, estimates using a large- $\boldsymbol{n}$ sample of workplace-level data are likely to be contaminated by unobserved aspects of the workplace that are correlated with both the independent variables and the dependent variable, biasing the estimated effects of the

\footnotetext{
${ }^{2}$ WERS2004 offers an additional measure used to construct alternative operationalizations of the dependent variable. Specifically, the survey asks, "Has management introduced or upgraded other types of new technology in this workplace in the last 2 years?" Ostensibly, "other technologies" could include forms of IT other than computers. However, it might also include other innovations not qualifying as hardware, software, or peripherals. This threat to validity made it a less attractive choice as a dependent variable. Nonetheless, every model in this paper yields qualitatively similar estimates when this alternative dependent variable or one that combines computers and "other technologies" is inserted in place of the more conservative, computers-only dependent variable. These alternative specifications are available from the author.
} 


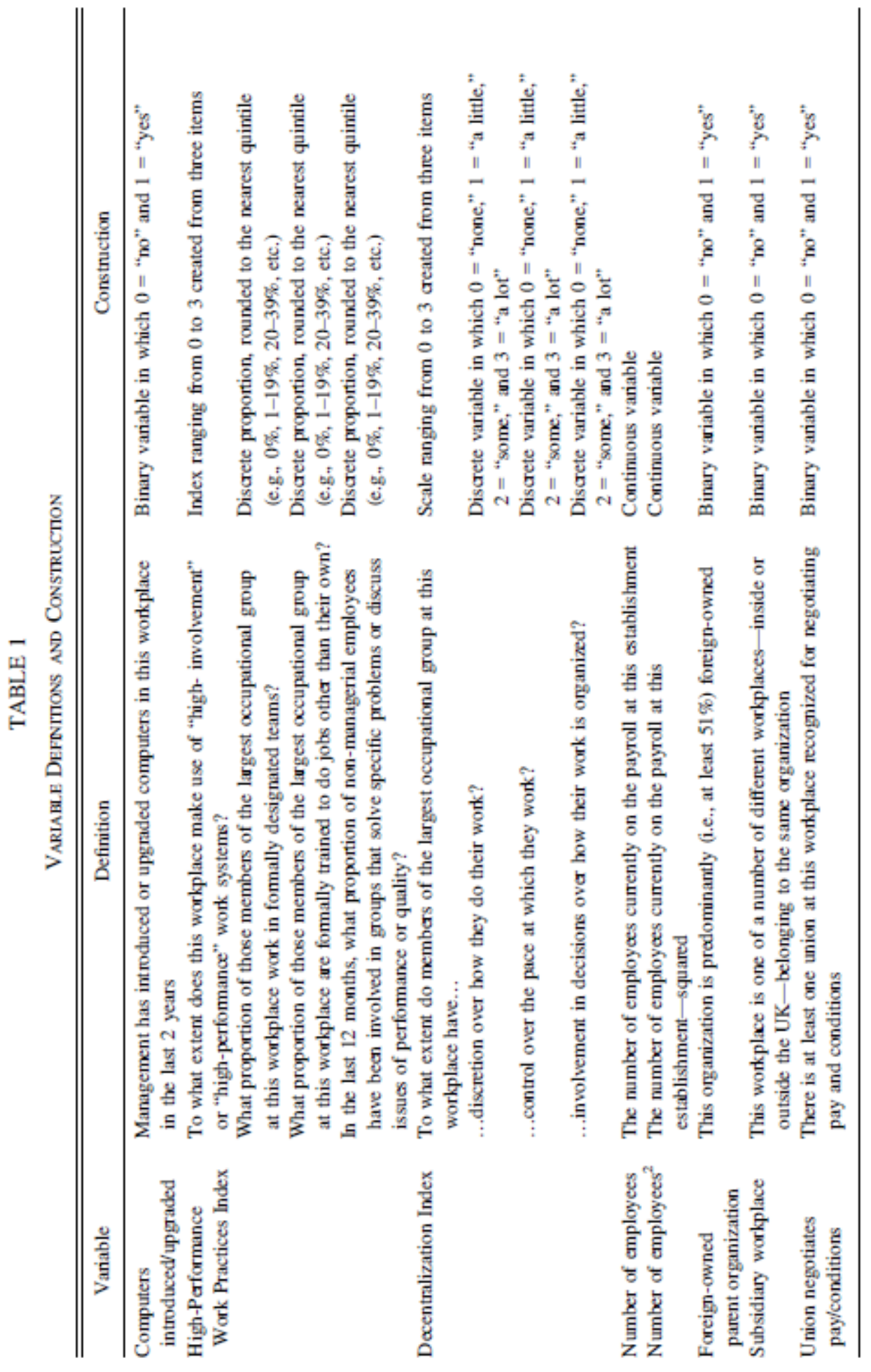




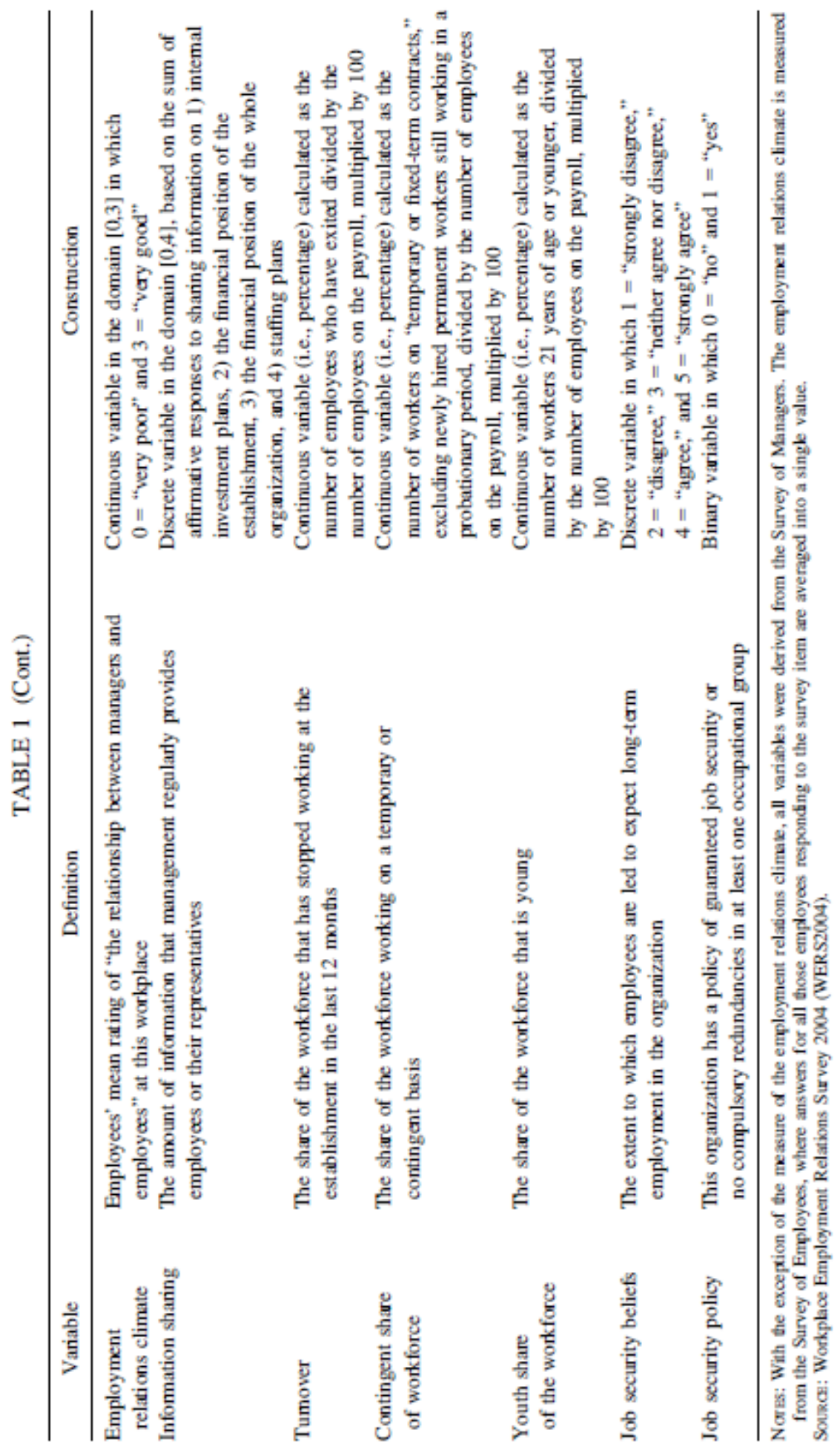

focal, independent variables. In the present case, one can imagine the overall nature of the relationship between managers and their employees being one such variable. That is, some workplaces are characterized by "good" employment relations, in which workers generally feel well treated, and managers feel they are respected by their employees and satisfied by the work employees do. Such a positive climate may also portend "labor peace" or general stability of the workplace. To the extent that a positive employment relations climate and general workplace stability correlate positively with both HRM and investment, the omission of this variable would bias upward the positive estimated impact of the measure of HPWPs as well as the measure of decentralization. As noted above, the measure of the employment relations climate is constructed not from management-provided data, but rather from data 
provided by their employees. Each worker respondent describes the employment relations climate from a single survey item, one that has been used in a number of prior studies to assess the employment relations climate in the UK and the United States (e.g., Fernie and Metcalf 1995; Welbourne and Andrews 1996). The mean answer for each workplace becomes its value for the employment relations climate. Aside from employment relations climate, a second broad construct that could drive both the HRM variables and IT investment is progressive, open-minded managers. That is, one could argue that some managers are especially well trained, well read, or well informed and thus are inclined toward innovative methods for managing their workers as well as toward the use of new technologies. The paper measures and controls for progressive management by summing answers to four questions regarding information sharing. That is, some managers regularly provide their workers (or worker representatives) updates on internal investment plans, the financial position of the establishment, the financial position of the firm, and on staffing plans. The sum of affirmative responses to four yes-or-no questions on the survey yields each establishment's value for this measure of information sharing.

In addition to these independent variables, some of the estimates include twodigit industry dummies. These control for industryconstant unobservables that some may argue are correlated with both the HRM variables, on the one hand, and IT investment on the other. These include industry-level trade union density, product market concentration, or price pressures from international trade.

Additional Variables. The remaining variables in Table 1 will not be called on in the primary analysis, but will be used to bolster the robustness of the estimated link between HRM and IT investment. In particular, the establishment' s annual rate of turnover will be used to predict the extent to which the workplace employs HPWPs, the logic being that high-turnover workplaces will be less likely than others to invest in the creation of formally designated teams and in cross-training and will be less reliant on the use of frontline workers to solve production problems (Batt and Colvin 2011; Lynch 1991). Other ascriptions of the establishment's workforce will be used as alternative measures of decentralization. In particular, the share of the workforce that is nonpermanent, the share of the workforce that is under 21 , and two measures of job security will be used to predict decentralization. This is based on the notion that managers will be systematically less likely to offer discretion and autonomy to frontline workers when these workers do not have interests that are tightly aligned with those of the firm (Holmstrom and Milgrom 1994; Mil-grom and Roberts 1992). The use of these variables is detailed below.

\section{Results}

Table 2 reports means, standard deviations, and zero-order correlations for the aforementioned variables. Notice that almost three quarters of the sample report having introduced or upgraded computers over the prior 2 years. Furthermore, IT investment is not strongly pairwise correlated with any of the other variables in the study. In particular, it is only weakly correlated with HPWPs (q = 0.12) and with decentralization $(q=0.11)$. Further examining the two focal independent variables, note that both have a mean somewhere on the right-hand side of their respective domains. Both are measured on 0-3 scales, and both fall at about 1.75. That is, the mean establishment in the sample reports some incidence (1.71) of HPWPs for their workers and provides workers with moderate to high (1.81) levels of autonomy and discretion. Not only are the HRM variables only weakly correlated with IT adoption in the absence of controls, they are also only weakly associated with one another, offering evidence of discriminant validity with respect to these two measures (Schwab 2005).

With respect to the other variables, there is much variation in workplace size across the sample, with large workplaces predictably 
over-sampled relative to smaller ones. ${ }^{3}$ Thirteen percent of the sample was foreign-owned, and 77 percent were branches of a larger, parent organization. Unions negotiate pay and conditions for at least some employees at just under half (46 percent) of those establishments in the sample. On average, employees in the sampled establishments view the employment relations climate somewhat positively (1.69 on a 0-3 scale), and managers claim to share information with workers on about 2.5 of the four domains captured in the measure. Interestingly, one might anticipate that all of the pairwise relationships formed by the employment relations climate, information sharing, the two HRM variables, and the dependent variable would be strong and positive. In fact, none of these correlations is strong, and the measure of the employment relations climate is actually negatively correlated with IT investment, the HPWP index, and with information sharing. Information sharing, however, is positively associated with IT investment and both HRM variables.

Turning briefly to the variables that will be used for robustness checks, mean turnover for the establishments in the dataset is about 19 percent per year, 9.3 percent of employees work on a contingent basis, and 8.4 percent of employees are 21 years of age or younger. While under 20 percent of the workplaces surveyed offer any of their employees any assurance of job security, on average, managers "agreed" that their employees were led to expect long-term employment in the organization. Workplaces that disproportionately relied on young workers, not surprisingly, were more likely to report higher turnover.

Probit regression is an appropriate technique for modeling the relationship between HRM and IT investment given the dichotomous nature of the dependent variable (Aldrich and Nelson 1984). This amounts to estimating

$$
\operatorname{Pr}\left(y_{i} \neq 0 \mid X_{i}\right)=\Phi\left(X_{i} \beta\right)
$$

where $\boldsymbol{y}_{\boldsymbol{i}}$ e $\{0,1\}$ is the observed value for the IT adoption variable for workplace $\boldsymbol{i}, \boldsymbol{X}_{\boldsymbol{i}}$ is the vector of independent variables and $ß$ their associated coefficients, $U$ is the standard cumulative normal distribution, and $\left(X_{i} ß\right)$ is the probit score. Table 3 reports estimates of equation (1). The first model includes only the control variables. It establishes the curvilinearity of the relationship between establishment size and the probability of IT adoption. That is, the likelihood of having invested in IT increases, but at a slightly decreasing rate, as the number of employees in the organization increases. Note that foreign ownership status, subsidiary status, union status, and the employment relations climate are not significant predictors of IT investment, nor do they become so in any of the other specifications in Table 3. In fact, other than size, the only independent variable that drives IT adoption in Model 1 in a substantively and statistically significant manner is information sharing. While the direction and statistical significance of the estimate are of greatest concern, one can say more precisely that a single-unit increase in information sharing, holding all of the other variables in place at their means, is associated with a 0.17 standard deviation increase in the probit score. That amounts to a 6.1 percentage point increase in the probability that a workplace reports having invested in IT. ${ }^{4}$

\footnotetext{
${ }^{3}$ Note the quadratic measure of establishment size has been divided by 10,000 to facilitate its display in the tables.

${ }^{4}$ For any continuous independent variable, $x, d U / d x=/(X \beta) b_{x}$, where $X$ is the vector of sample means for the independent variables, $\beta$ is the vector of their associated coefficients, and $b x$ is the estimate for $x$. / is the height of the normal density function. The formula differs only slightly for binary $x$.
} 


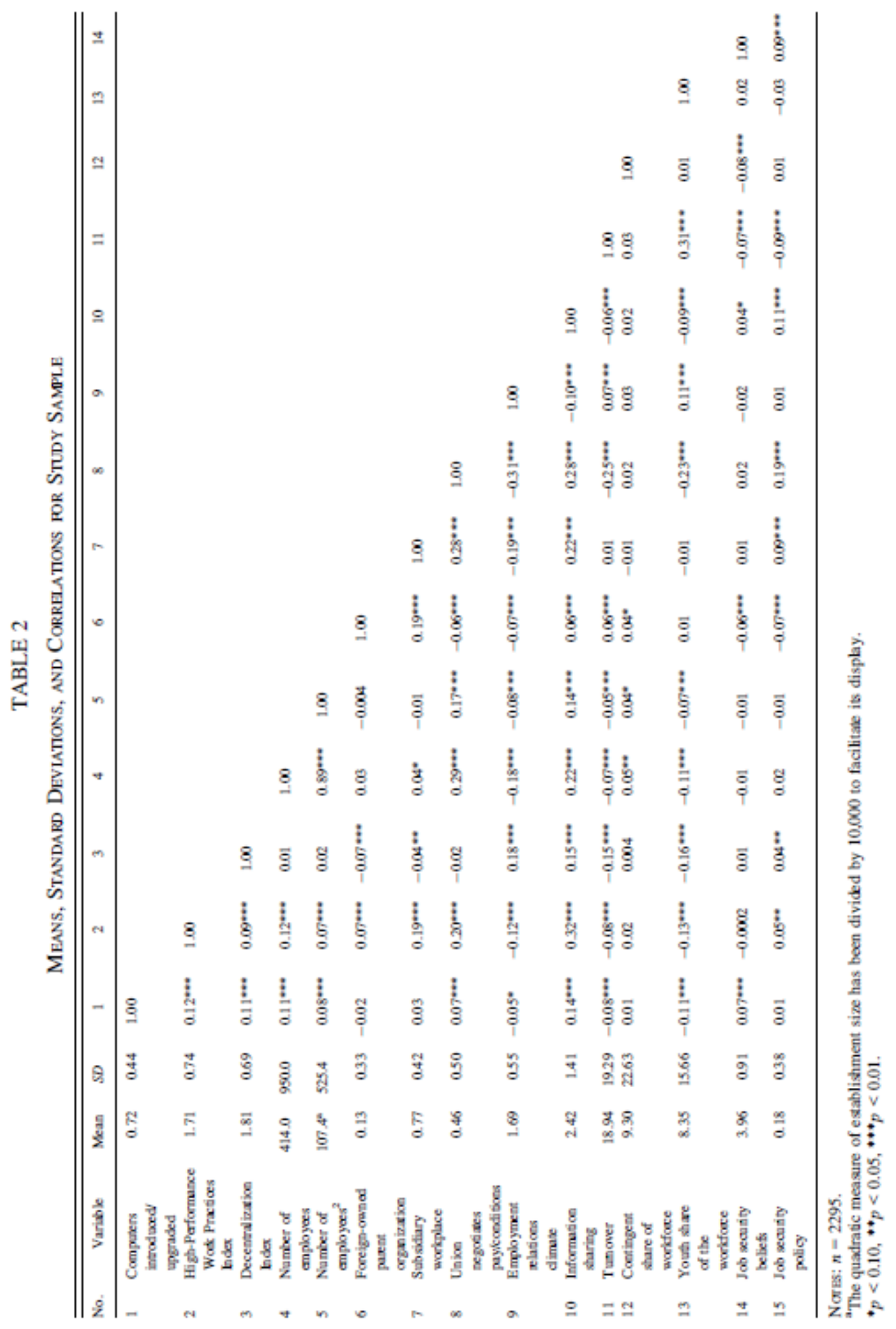




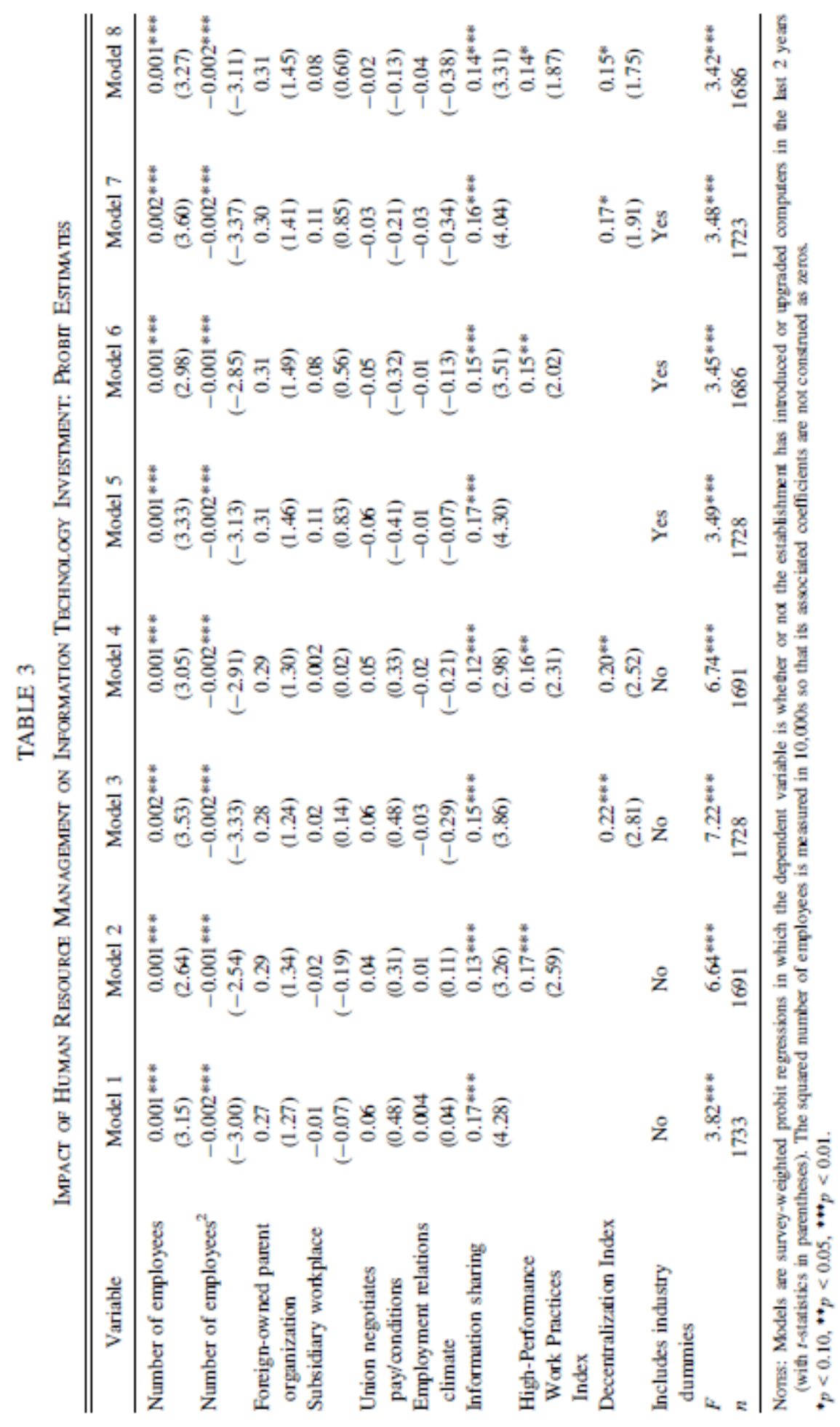

Model 2 adds the HPWP index to the right-hand side. As hypothesized, it enters into the equation with a positive and statistically significant slope coefficient. In this case, holding all of the other variables at their means, a singleunit increase in the HPWP index increases the likelihood of IT investment by about 6.4 percentage points. ${ }^{5}$ Model 3 instead adds the decentralization index rather than the HPWP index to the right-hand side, revealing that a single-unit increase in decentralization increases the likelihood of IT investment by 8.1 percentage points. Interestingly, the estimated coefficient on information sharing declines in Models 2 and 3 relative to its value

${ }^{5}$ In the case of the HPWP coefficient in Model $2, \beta=0.173$, whereas the information sharing coefficient in Model 1 is actually 0.166. 
in Model 1, suggesting that the information sharing measure had initially been biased upward by the omission of the HRM measures. Finally, Model 4 includes both focal HRM measures on the right-hand side simultaneously. Both coefficients maintain their direction, with only slight declines in their magnitude and slight increases in their estimated standard errors. Both remain highly statistically significant.

Models 5-8 in Table 3 re-estimate the previous four models, only adding the vector of two-digit industry dummies. As a result, these estimates can be interpreted as "within-industry" estimates. In Model 5, for example, the 0.17 coefficient on information sharing implies that holding all the other variables at their sample means, a single-unit increase in the measure of information sharing increases the likelihood of IT investment by 6.3 percentage points relative to other establishments in the same industry. That is, even after controlling for the vector of observable variables as well as for all unobserved, industry- level factors relating to labor and product markets-or to the potential usefulness of IT-increases in information sharing are still associated with an increased likelihood of IT investment. The estimates in Models 6, 7, and 8 parallel those in Models 2, 3, and 4. Note that the inclusion of industry dummies only slightly dampens the magnitude and precision of the effects of the two focal HRM variables. All estimates maintain their hypothesized direction and continue to achieve conventional levels of statistical significance.

Robustness Checks. Endogeneity would be the single biggest challenge to the probit estimates above. That is, one could argue that the two HRM variables are correlated with the error term, thus biasing their estimated effects upwards. There are at least two ways by which this could come about - reverse causality or omitted variables. With respect to the reverse causality, it is possible given the cross-sectional nature of the dataset and the timing of the survey that establishments bought new technology, and then altered their work practices accordingly. Of course, once we accept that managers make decisions based on mere expectations regarding the ease with which the technology can be deployed (Willman 1986), the precise timing of the incidence of HRM and the investment in IT becomes less crucial. In fact, received empirical work shows that IT diffusion often leads necessitated organizational changes by several years (Bartel, Ichniowski, and Shaw 2007; Brynjolfsson and Hitt 2003). The endogeneity resulting from omitted variables is, perhaps, the larger challenge to the probit estimates. That is, any variable not explicitly observed and controlled for that would be a positive driver of both the HRM variables and IT investment could end up loading onto the coefficients of the HRM variables, yielding estimated slope parameters in excess of their true values.

The most likely culprits in a study like this one would be the extent to which managers are progressive or open-minded or the overall quality of the employees or of their relationship with management. That is, it could be that progressive managers, for example, are both more likely to adopt innovative employment practices and work structures and more likely to rely on new technologies. Similarly, one could reasonably argue that a healthy relationship between managers and their workers would drive managers to experiment with HPWPs or decentralization while signaling a more certain climate for gaining returns from new investments in IT. In fact, that the probit estimates include controls for the employment relations climate and information sharing, a proxy for progressive management, offers some defense against omitted variable bias. Furthermore, the estimates that include two-digit industry dummies control for all unobservable variables, albeit at the industry level rather than the level of the individual establishment.

A second direction from which to address potential endogeneity in crosssectional data is through a two-stage estimation framework. It requires first regressing the focal HRM variables on one or more instrumental variables (IVs), and then using these estimates to predict IT adoption in the second stage. Two conditions must be met to do this credibly (Wooldridge 2010). ${ }^{6}$ First, one must identify one or more IVs expected to be highly correlated with each of the two HRM variables. Second, as these IVs must

${ }^{6} \mathrm{~A}$ third condition, monotonicity, is also important, although rarely given much attention. 
necessarily be excluded from the second-stage equations, one must be willing to assume that the IVs themselves do not have a direct effect on the IT adoption decision, net of the other variables controlled for in the second stage.

Turning first to the HPWP index, there is good reason to believe that establishments with high turnover are systematically less likely to adopt the HPWPs included in the index. That is, firms with a revolving door for workers should be less likely to establish formal teams and less likely to invest in cross-training (Batt and Colvin 2011). Furthermore, where workers turn over frequently, they are less likely to have a well-developed base of tacit or explicit knowledge to leverage toward problem solving (Batt 2002). However, there is no obvious reason why low- or high-turnover establishments would be more or less likely to invest in IT. Therefore, one should be able to use turnover to instrument for HPWPs, boosting the causal credibility of the probit estimates in Table 3 by further countering charges of bias resulting from endogeneity.

In considering the exogenous determinants of decentralization, it makes sense to consider the situations under which managers are likely to push decision-making authority down to the frontlines. In general, managers must trust that workers' interests are systematically aligned with those of the firm and that frontline workers have the knowledge and information necessary to make rational, profit-maximizing decisions on their own (Holmstrom and Milgrom 1994; Milgrom and Roberts 1992). Following this line of thought, determinants of decentralization should include the share of the establishment' s labor force that is under 21 , and thus, inexperienced, as well as the share of the workers attached to the establishment on a purely temporary basis. Similarly, one could also imagine that measures of job security-either in the form of concrete employment guarantees or in terms of expectations promulgated by management would be positive drivers of decentralization. That is, managers are more likely to devolve authority when frontline workers are vested in the firm (Jensen and Meckling 1992). However, once again, there is no a priori reason to expect that firms that rely heavily on "temps" or young workers or establishments that make little or no effort to convey a sense of job security for their workers would be more or less likely to invest in IT.

To the extent one accepts these arguments, Table 4 offers evidence that bolsters the original probit estimates presented in Table 3. It reports the estimates of the two-stage probit regressions, which are consistent with the single-stage estimates in Table 3. With or without industry dummies, increases in either the HPWP index or the decentralization index are associated with an increased propensity for IT investment. As with the single-stage probit estimates in Table 3, we should be more concerned with the direction and statistical significance of the coefficients than with the magnitude of the estimates. However, it is interesting that the two-stage estimates are all larger than their counterparts in Table 3. One possible explanation would be that the earlier probit estimates are biased toward zero due to measurement error in the HRM variables. Therefore, while it is critical to note that no estimates can ever be completely and assuredly purged of omitted variable bias, particularly in the context of single observation, cross-sectional data, the two-stage estimates nonetheless offer an additional bulwark against endogeneity as the source of the positive effects of HRM evidenced in Table 3.

Aside from endogeneity, it is also possible that the simple models estimated in Table 3 are masking unobserved heterogeneity in HRM effects based on the values of the binary variables. That is, one could argue, for example, that the impact of HPWPs or decentralization on IT investment exists only for foreign- owned establishments. There may even be a theoretical case to be made for HRM having a potentially differential impact on investment in unionized firms, as Bryson, Forth, and Kirby (2005) have shown to be the case with respect to other organizational outcomes. In both the case of foreign ownership and of union status and for each of the two HRM measures, there is no evidence of heterogeneity. Estimates that include all of the main effects plus the two-way multiplicative interaction variables reveal no change in sign or significance for the main effects and insignificant point estimates on the two, twoway interaction terms. Nonetheless, the results for the union estimates should be taken with a grain of salt given the 
TABLE 4

Impact of Human Resource Management on Information Technology Investment: Two-Stage

Probit Estimates

\begin{tabular}{|c|c|c|c|c|}
\hline Variable & Model 1 & Model 2 & Model 3 & Model 4 \\
\hline Number of employees & $-0.0002(-0.33)$ & $0.002^{* * *}(4.41)$ & $-0.0001(-0.12)$ & $0.002^{* * *}(4.52)$ \\
\hline Number of employees ${ }^{2}$ & $0.001(0.60)$ & $-0.004^{* * *}(-3.76)$ & $0.0004(0.32)$ & $-0.004^{* * *}(-3.68)$ \\
\hline $\begin{array}{l}\text { Foreign-owned } \\
\text { parent organization }\end{array}$ & $0.26(1.21)$ & $0.24(1.06)$ & $0.20(0.86)$ & $0.26(1.23)$ \\
\hline Subsidiary workplace & $-0.09(-0.78)$ & $0.12(0.97)$ & $-0.22(-1.12)$ & $0.14(1.07)$ \\
\hline $\begin{array}{l}\text { Union negotiates } \\
\text { pay/oonditions }\end{array}$ & $-0.13(-0.87)$ & $0.05(0.37)$ & $0.03(0.22)$ & $0.04(0.23)$ \\
\hline $\begin{array}{l}\text { Employment relations } \\
\text { climate }\end{array}$ & $0.05(0.64)$ & $-0.13(-1.19)$ & $-0.04(-0.45)$ & $-0.13(-1.06)$ \\
\hline Information sharing & $-0.11(-1.08)$ & $0.09 *(1.95)$ & $-0.08(-0.52)$ & $0.11^{* *}(2.09)$ \\
\hline $\begin{array}{l}\text { High-Performance } \\
\text { Work Practices Index }\end{array}$ & $1.06^{* * *}(5.06)$ & & $1.11^{* * *}(2.86)$ & \\
\hline Decentralization Index & & $0.89 * * *(4.01)$ & & $0.78 * *(2.09)$ \\
\hline $\begin{array}{l}\text { Includes industry } \\
\text { dummies }\end{array}$ & No & No & Yes & Yes \\
\hline$F$ & $46.49^{* * *}$ & $12.01^{* * *}$ & $13.32^{* * *}$ & $14.42^{* * *}$ \\
\hline$n$ & 1595 & 1635 & 1590 & 1630 \\
\hline
\end{tabular}

Nores: Models are survey-weighted, two-stage probit regressions in which the dependent variable is whether or not the establishment has introduced or upgraded computers in the last 2 years (with t-statistics in parentheses). The squared number of employees is measured in $10,000 \mathrm{~s}$ so that its associated coefficients are not construed as zeros.

${ }^{*} p<0.10,{ }^{* *} p<0.05,{ }^{* * *} p<0.01$.

coarse nature of the unionization measure employed in this study.

The results for the interactions involving the subsidiary status of a workplace- whether or not the establishment is one of multiple workplaces belonging to the same organization-are more revealing. In this case, one might argue that the inclusion of two-way interaction terms between the HRM variables and subsidiary status could reveal that the theorized relationships between HRM measures and IT investment exist only for standalone workplaces. That is, one might expect that at subsidiary workplaces, decisions regarding employment practices and IT investment are made outside and above the establishment level, or at least influenced by unobserved processes and structures at these higher levels (Becker and Gerhart 1996; Ichniowski and Shaw 2003; Osterman 1994). In this case, the original results regarding subsidiary status are robust to the inclusion of two-way interaction terms. Still, the estimates are informative. The main effect of subsidiary status, insignificant in the probit models presented in Table 3, becomes positive and statistically significant, likely signaling the larger scale and scope of the organizations in which these workplaces are ensconced. Moreover, the effects of the HRM variables remain strongly positive and significant. However, both two-way interaction terms carry a statistically significant negative coefficient, suggesting that the connection between the HRM variables and investment is slightly weaker for subsidiary workplaces than for self-standing ones. Indeed, it would be somewhat troubling if this were not the case. Nonetheless, by examining linear combinations of coefficients, one can see that the negative effect of subsidiary status is nowhere near enough to offset the positive impact of either HRM variable. ${ }^{7}$

Finally, one could be concerned that effects attributed to each of the HRM indices are actually being driven by one or more of the individual items that comprise the index as opposed to the index per se. Given the way the two HRM variables are constructed, it is a straightforward exercise to decompose each index and to instead enter the individual items into the probit estimates. In the case of both indices, estimates attached to individual survey items do have the hypothesized, positive effect on IT investment. However, the

\footnotetext{
7 Owing to consistency issues that arise when introducing multiplicative interaction terms in probit or logistic regression models (Ai and Norton 2003), these models had to be estimated using a linear probability model. These alternative specifications are available from the author.
} 
magnitude and the statistical significance of the estimates for the indices are substantially larger than those for the individual items. This provides further evidence that the three elements of high performance, as measured in these data, really do belong together in an index and are properly theorized to influence IT investment in bundled form. The same can be said for the components of the decentralization index. This is consistent with notions of complementarity underpinning the high-performance work systems construct (Ichniowski, Shaw, and Prennushi 1997; MacDuffie 1995; Milgrom and Roberts 1995).

\section{Discussion and Conclusions}

When faced with the prospect of installing or upgrading computers, managers must make a strategic choice, one influenced by market, technological, and power constraints. Scholars of work and employment have long recognized that collective bargaining could be one such constraint, and therefore developed a rich literature relating collective bargaining to business investment. That research augmented the simple image of union featherbedding with a more nuanced explanation of the avenues by which employment relations structures and processes influence business investment. This study further advances and broadens this literature by widening the scope of the employment relationship beyond the union/nonunion divide, instead positing that HRM drives IT adoption. It does so by preparing the establishment-"feathering the nest" - for the considerable shock that new IT will exact upon production and service processes.

To reiterate, as managers generally do not choose whether or not to unionize in the same way that they exercise more direct control over their employment practice choices, it is important to stress that collective bargaining and HRM should not be construed as two parallel constructs influencing IT investment. Rather, the analysis shows that an establishment's status along two dimensions of HRM is positively associated with whether or not it has adopted new computing technology in the previous 2 years. Both of these employment relations features - the incidence of HPWPs and the degree to which frontline workers have autonomy and discretion position an establishment to gain more from IT than it would in the absence of these innovative practices. Specifically, HPWPs, namely teamwork, cross-training, and problem-solving groups, provide a more ideal structure for exploiting IT than do more conventional employment practices. Aside from these three practices complementing one another (Ichniowski, Shaw, and Prennushi 1997), they position workers to discover and employ novel uses for the technology (Kelley 1996; MacDuffie 1995). More broadly, IT pushes information down to frontline workers. Where they have the discretion to use it-measured above with a decentralization index, the technology will yield greater benefits than it would in an otherwise similar workplace with a more conventional, centralized approach to work and decision making. That is, the incidence of each of these measures of HRM appears to increase managers' expectations and certainty of returns attendant to IT investments. As a result, both measures positively predict the likelihood that a given workplace will undertake what could be a sizable investment in new computing technology.

From a theoretical standpoint, the findings offer an employment relations- related explanation aside from the presence of a powerful union as to why a firm might be slow to invest in IT: Managers may well understand that IT's performance returns are contingent upon their providing their workers with a high level of discretion or an innovative set of work structures, changes that managers may be unwilling or unable to implement. Even enlightened managers may simply realize that the upfront cost associated with modernizing their approach to managing people is too much for risk-averse or shortsighted shareholders to swallow, and that the tacit decision to maintain existing practices makes incumbent technologies more productive than new ones.

If these mechanisms play out in organizations, then the findings of this study also hint at selection issues in studies linking IT investment to business performance. Obviously, computers are not randomly assigned to a sample of firms, and it seems likely from this research that those firms embracing HRM recognize that they would be at an advantage in their ability to profit from IT investments. The estimates illuminate a parallel problem in the strategic HRM literature as well. Indicative of the contingent 
perspective, Godard (2004) reminds us that implementing innovative employment practices comes at a cost, suggesting that such practices are more likely to be adopted where managers expect the benefits to exceed the costs. Based on the present study, one could theorize that firms that choose an IT-dependent business strategy are uniquely positioned to make use of HPWPs, for example, and that strategic HRM performance analyses that neglect to account for technology are therefore fundamentally misspecified (Kaufman 2010).

Despite the fact that this study is founded in part on theory developed around collective bargaining, it is not making a direct contrast between IT investment under trade unions and IT investment under HRM. Given the binary operationalization of the union measurewhether or not one or more unions at the workplace negotiate over pay and conditions-readers should be wary making any definitive statements tying collective bargaining to IT investment based on this study. As the goal here was to link elements of HRM with IT investment, the key union-related issue to control for was actual collective bargaining. That is, it was meant to isolate the aspect of unionism that some argue dampens investment (Grout 1984) without picking up the positive aspects of unions that others have hypothesized (Freeman and Medoff 1984) and that should be measured with the HRM variables. The union measure, while suitable for this purpose, is insufficiently nuanced to meaningfully measure union effects. Again, this choice partially explains the insignificant relationship between unions and investment in the fully specified equations estimated in Tables 3 and 4 and even in the robustness checks that seek to cross unionization with each of the HRM measures.

Table 2 does reveal a bit about the relationship between collective bargaining and HRM. Almost half of the workplaces in the sample have at least one union recognized for negotiating pay and conditions, and the HPWP index, a measure of the innovativeness of an establishment's employment practices, is, in fact, very weakly but positively correlated with the presence of a union. Without controls, unionized workplaces are more likely to report the incidence of innovative employment practices like teamwork and cross-training, a finding that follows logically from the evidence that these practices have larger performance effects in unionized environments than in nonunion ones (Bryson, Forth, and Kirby 2005). The link between union status and the decentralization index, the measure of innovative work structures, is a bit more nuanced. In Table 2, the union measure is essentially uncorrelated with the decentralization. On the one hand, it makes sense that unionized workplaces would be more likely to retain a conventional work structure in which planning and decision making are centralized and separated from execution, the very model around which job-control unionism developed. On the other hand, we know that progressive unions and their management counterparts have been forerunners in bringing about new work structures in which autonomy and decision making are devolved from managers to frontline workers (e.g., Kochan et al. 2009). Therefore, one explanation for the lack of a zero-order correlation between unionism and decentralization is unobserved heterogeneity in bargaining structures and other features of labor-management relationships that, in this study, get characterized simply as "unionized."

Thus, the complexity of the association between collective bargaining and HRM and the inability to tease it apart with a binary measure of union presence actually "tees up" a worthwhile question for future research. Given evidence that unions and HRM complement rather than substitute for one another in production (Bryson, Forth, and Kirby 2005; Machin and Wood 2005), it remains to be determined whether or not that complementarity holds with respect to IT investment. Once one isolates those aspects of collective bargaining that can exist outside the unionized employment relationship, including aspects of HRM, is there still something unique about unionism as an institutional form that moderates the relationship between HRM and IT investment?

Despite the robustness checks tendered above, the possibility of endogeneity, chiefly the result of unobservable and thus, omitted variables, remains the one empirical issue that may give pause. In cross-sectional data, one can never completely preclude the existence of nebulous factors that drive both the reorganization of work and the probability of innovation, the absence of which could 
bias up the effects of HRM on investment. A two-pronged effort is made, however, to counter this issue. First, to the extent that one might expect broadly progressive management or a generally positive assessment of establishment-level employment relations to be the culprit, an earnest attempt has been made to control for both. Interestingly, employees' perceptions of the labor relations climate do not appear to have a direct effect on IT investment. More important, controlling for the employment relations climate in this way does not alter the paper's fundamental findings. Likewise, the forward-looking nature or openmindedness of managers is measured by the extent to which they share four different kinds of production-, work-, and finance-related information with their employees. Not surprisingly, this measure had a strong and direct impact on IT investment. Again, however, what is more critical is that the hypothesized, estimated impact of the focal HRM variables emerged even in the presence of this important control variable.

In addition to the inclusion of these catch-all control variables, the initial estimates were followed up with a two-stage procedure in which the HPWP and decentralization indices were instrumented for using variables that describe the composition of the workforce and the nature of workers' attachment to their employers. While the credibility of these two-stage estimates rests on one's acceptance of the exogeneity of the chosen instruments, these estimates, too, reveal a statistically significant positive relationship between each of the HRM variables and IT investment. That is, the main results of the paper withstand this alternative estimation approach.

Notwithstanding these challenges, this study offers advantages from an empirical standpoint relative to the few existing studies linking IT to work practices, both of which were undertaken mainly as a prelude to very rich analyses of the combined performance effects of human and technological capital - Hitt and Brynjolfsson's (1997) cross-industry study of firms and Bartel, Ich- niowski, and Shaw's (2007) study of valve-making plants. Relative to those studies, this study encompassed a broader swath of workplaces in terms of workplace size and the span of industries covered. This study also had a sample size about 8-10 times that of either of the previous studies. Finally, this study had the highest response rate of the three studies, by more than 10 percentage points. These previous studies nonetheless offer valuable insight that can only come from self-collected data and a deep understanding of workplace context. When coupled with the findings from this study, they suggest that subsequent research should more closely examine the determinants of IT investment in a specific industry or even in a specific type of workplace in a single industry. In the United States, the public sector's active encouragement of health IT and electronic health record (EHR) adoption (Litwin 2010), backed by billions of dollars in state and federal money, points to hospitals and medical centers as the ideal setting for further unpacking the sorts of employment structures that position organizations for IT investment. It could well be that the slow diffusion of EHR systems, for example, can be readily explained by a dearth of HRM or other employment relations structures in U.S. medical delivery settings.

Although it has been shown that employment relations research anticipated much of present-day strategic HRM (Kaufman 2001), there remain precious few extensions of collective bargaining research to other, often nonunion- related management phenomena. This analysis of HRM drivers of IT investment offers just one example of this sort of extension, exemplifying the ways that theory first developed in heavily unionized settings can be drawn upon to link employment practices to investments in IT. To the extent that it considers investment behavior, it also opens the door to a wide range of research linking firms' decisions in the financial realm to their approaches to managing people and organizing work. In that sense, studies like this one can also hasten the incorporation of issues of businesses' capital formation and investment behavior into employment relations theory and research. 
Addison, John T., Thorsten Schank, Claus Schnabel, and Joachim Wagner. 2007. “Do Works Councils Inhibit Investment?" Industrial and Labor Relations Review 60(2): 187-203.

Ai, Chunrong, and Edward C. Norton. 2003. “Interaction Terms in Logit and Probit Models." Economics Letters 80(1): 123-29.

Aldrich, John H., and Forrest D. Nelson. 1984. Linear Probability, Logit, and Probit Models. Beverly Hills, CA: Sage.

Badham, Richard John. 2005. "Technology and the Transformation of Work." In Oxford Handbook of Work and Organization, edited by Stephen Ackroyd, Rosemary Batt, Paul Thompson, and Pamela Tolbert, pp. 115-37. New York: Oxford.

Bartel, Ann, Casey Ichniowski, and Kathryn Shaw. 2007. "How Does Information Technology Really Affect Productivity? Plant-Level Comparisons of Product Innovation, Process Improvement and Worker Skills." Quarterly Journal of Economics 122(4): $1721-58$.

Batt, Rosemary L. 1999. "Work Organization, Technology, and Performance in Customer Service and Sales." Industrial and Labor Relations Review 52(4): 539-64.

2002. "Managing Customer Services: Human Resource Practices, Quit Rates, and Sales Growth." Academy of Management Journal 45(3): 587-97.

, and Alexander J. S. Colvin. 2011. "An Employment Systems Approach to Turnover: Human Resources Practices, Quits, Dismissals, and Performance." Academy of Management Journal 54(4): 695-717.

Becker, Brian E., and Barry Gerhart. 1996. "The Impact of Human Resource Management on Organizational Performance: Progress and Prospects." Academy of Management Journal 30(4): 779-801.

, and Mark A. Huselid. 1998. "High Performance Work Systems and Firm Performance: A Synthesis of Research and Managerial Implications. " In Research in Personnel and Human Resources Management, edited by Gerald Ferris, pp. 53-101. Greenwich, CT: JAI.

Bresnahan, Timothy F., Erik Brynjolfsson, and Lorin M. Hitt. 2000. "Technology, Organization, and the Demand for Skilled Labor." In The New Relationship: Human Capital in the American Corporation, edited by Margaret M. Blair and Thomas A. Kochan, pp. 14584. Washington, DC: Brookings Institution.

„, and - . 2002. "Information Technology, Workplace Organization, and the Demand for Skilled Labor: Firm Level Evidence." Quarterly Journal of Economics 117(1): 339-76.

Bronars, Stephen G., Donald R. Deere, and Joseph S. Tracy. 1994. "The Effects of Unions on Firm Behavior: An Empirical Analysis Using Firm-Level Data." Industrial Relations 33(4): 426-51.

Brynjolfsson, Erik, and Lorin M. Hitt. 2003. “Computing Productivity: Firm-Level Evidence." Review of Economics and Statistics 85(4): 793-808.

„, and Shinkyu Yang. 2002. "Intangible Assets: Computers and Organizational Capital.” Brookings Papers on Economic Activity 2002(1): 137-81.

, and Adam Saunders. 2010. Wired for Innovation: How Information Technology Is Reshaping the Economy. Cambridge, MA: MIT.

Bryson, Alex, John Forth, and Simon Kirby. 2005. "High-Involvement Management Practices, Trade Union Representation and Workplace Performance in Britain." Scottish Journal of Political Economy 52(3): 451-91.

Budd, John W. 2010. Labor Relations: Striking a Balance. New York: McGraw-Hill/Irwin.

Cappelli, Peter, and David Neumark. 2001. “Do 'High-Performance' Work Practices Improve Establishment- Level Outcomes?” Industrial and Lahor Relations Review 54(4): 737-75.

Denny, Kevin, and Stephen J. Nickell. 1992. “Unions and Investment in British Industry.” Economic Journal 102(413): 874-87.

Department of Trade and Industry. 2005. Workplace Employment Relations Survey: Cross-Section, 2004 [computer file], 1st ed. Colchester: The Data Archive [distributor].

Dunlop, John T. [1958] 1993. Industrial Relations Systems. Boston: Harvard Business School.

Farber, Henry S. 1986. "The Analysis of Union Behavior." In Handbook of Labor Economics, edited by Orley C. Ashenfelter and Richard Layard, pp. 1039-89. New York: North-Holland.

Fernie, Sue, and David Metcalf. 1995. “Participation, Contingent Pay, Representation and Workplace Performance: Evidence from Great Britain." British Journal of Industrial Relations 33(3): 379-415.

Ferris, Gerald, Donald Barnum, Sherman Rosen, Lawrence Holleran, and James Dulebohn. 1995. "Toward Business-University 
Partnership in Human Resource Management: Integration of Science and Practice." In Handbook of Human Resource Management, edited by Gerald Ferris, Sherman Rosen, and Donald Barnum, pp. 1 -13. Oxford: Blackwell.

Freeman, Richard B. 1976. “Individual Mobility and Union Voice in the Labor Market." American Economic Review 66(2): 361-68.

, and James L. Medoff. 1984. What Do Unions Do? New York: Basic Books.

Godard, John. 2004. "A Critical Assessment of the High-Performance Paradigm.” British Journal of Industrial Relations 42(2): 349-78.

Grout, Paul A. 1984. "Investment and Wages in the Absence of Binding Contracts: A Nash Bargaining Approach." Econometrica 52(2): 449-60.

Hirsch, Barry T. 1992. "Firm Investment Behavior and Collective Bargaining Strategy." Industrial Relations 31(1): 95-121.

, and Albert N. Link. 1987. “Labor Union Effects on Innovative Activity.” Journal of Labor Research 8(4): 323.

Hitt, Lorin M., and Erik Brynjolfsson. 1997. "Information Technology and Internal Firm Organization: An Exploratory Analysis." Journal of Management Information Systems 14(2): 81-101.

Holmstrom, Bengt, and Paul Milgrom. 1994. "The Firm as an Incentive System." American Economic Review 84(4): 972-91.

Huber, George P., and Daniel J. Power. 1985. "Retrospective Reports of Strategic-Level Managers: Guidelines for Increasing Their Accuracy." Strategic Management Journal 6(2): 171-80.

Hunter, Larry W., and John J. Lafkas. 2003. "Opening the Box: Information Technology, Work Practices, and Wages." Industrial and Labor Relations Review 56(2): 224--3.

, and Frits K. Pil. 1995. "How Do You Survey Firms?” In Proceedings of the 47th Annual Meeting of the Industrial Relations Research Association, edited by Paula B. Voos, pp. 152-62. Madison, WI: IRRA.

Ichniowski, Casey, and Kathryn Shaw. 2003. “Beyond Incentive Pay: Insiders' Estimates of the Value of Complementary Human Resource Management Practices." Journal of Economic Perspectives 17(1): 155-80.

,, and Giovanna Prennushi. 1997. "The Effects of Human Resource Management Practices on Productivity: A Study of Steel Finishing Lines." American Economic Review 87(3): 291-313.

, Thomas A. Kochan, David Levine, Craig Olson, and George Strauss. 1996. "What Works at Work: Overview and Assessment." Industrial Relations 35(3): 299-333.

Jensen, Michael C., and William H. Meckling. 1992. "Knowledge, Control, and Organizational Structure: Parts I and II." In Contract Economics, edited by Lars Werin, and Hans Wijkander, pp. 251-74. Cambridge, MA: Blackwell.

, and------- . 1995. “Specific and General Knowledge, and Organizational Structure.” Journal of Applied Corporate Finance 8(2): 4-18.

Kanigel, Robert. 1997. The One Best Way: Frederick Winslow Taylor and the Enigma of Efficiency. New York: Viking.

Kaufman, Bruce E. 2001. "The Theory and Practice of Strategic HRM and Participative Management: Antecedents in Early Industrial Relations." Human Resource Management Review 11(4): 505-33.

2004. "Toward an Integrative Theory of Human Resource Management." In Theoretical Perspectives on Work and the Employment Relationship, edited by Bruce E. Kaufman, pp. 321-66. Champaign, IL: Industrial Relations Research Association.

2010. "SHRM Theory in the Post-Huselid Era: Why It Is Fundamentally Misspecified." Industrial Relations 49(2): 286-313.

Keefe, Jeffrey H. 1991. “Do Unions Influence the Diffusion of Technology?” Industrial and Lahor Relations Review 44(2): 261 -74.

Kelley, Maryellen R. 1996. "Participative Bureaucracy and Productivity in the Machined Products Sector." Industrial Relations 35(3): 374-99.

Kersley, Barbara, Carmen Alpin, John Forth, Alex Bryson, Helen Bewley, Gill Dix, and Sarah Oxenbridge. 2006. Inside the Workplace: Findings from the 2004 Workplace Employment Relations Survey. New York: Routledge.

Kochan, Thomas A., Harry C. Katz, and Robert B. McKersie. 1986. The Transformation of American Industrial Relations. New York: Basic Books.

, Robert B. McKersie, and Peter Cappelli. 1984. "Strategic Choice and Industrial Relations Theory." Industrial Relations 23(1): 1639.

, and Paul Osterman. 1994. The Mutual Gains Enterprise: Forging a Winning Partnership Among

Lahor, Management, and Government. Boston: Harvard Business School. 
, Adrienne E. Eaton, Robert B. McKersie, and Paul S. Adler. 2009. Healing Together: The LahorManagement Partnership at Kaiser Permanente. Ithaca, NY: Cornell/ILR.

Latreille, Paul L. 1992. "Unions and the Inter-Establishment Adoption of New Microelectronic Technologies in the British Private Manufacturing Sector." Oxford Bulletin of Economics and Statistics 54(1): 31-51.

Litwin, Adam Seth. 2010. Why Don't Docs Digitize? The Adoption of Health Information Technology in Primary Care Medicine. \#1431202. Chicago: SSRN.

. 2011. "Technological Change at Work: The Impact of Employee Involvement on the Effectiveness of Health Information Technology." Industrial and Lahor Relations Review 64(5): 863-88.

Lynch, Lisa M. 1991. "The Role of Off-the-Job vs. On-the-Job Training for the Mobility of Women Workers". American Economic Review 81: 151-56.

MacDuffie, John Paul. 1995. "Human-Resource Bundles and Manufacturing Performance: Organizational Logic and Flexible Production Systems in the World Auto Industry." Industrial and Lahor Relations Review 48(2): 197-221.

Machin, Stephen, and Sushil Wadhawni. 1991. "The Effects of Unions on Investment and Innovation: Evidence from WIRS." Economic Journal 101(405): 324-30.

, and Stephen Wood. 2005. "Human Resource Management as a Substitute for Trade Unions in British Workplaces." Industrial and Lahor Relations Review 58(2): 201-18.

Milgrom, Paul, and John Roberts. 1990. "The Economics of Modern Manufacturing: Technology, Strategy, and Organization." American Economic Review 80(3): 511-28.

, and-------- . 1992. Economics, Organization and Management. Upper Saddle River, NJ: Prentice Hall.

, and------- . 1995. “Complementarities and Fit: Strategy, Structure, and Organizational Change in Manufacturing." Journal of Accounting and Economics 19(2-3): 179-208.

Murray, R. Emmett. 1998. The Lexicon of Lahor. New York: New Press.

Noble, David F. 1984. Forces of Production: A Social History of Industrial Automation. New York: Knopf.

Osterman, Paul. 1994. “How Common Is Workplace Transformation and Who Adopts It?” Industrial and Labor Relations Review 47(2): 173-88.

Podsakoff, Philip M., Scott B. MacKenzie, Jeong-Yeon Lee, and Nathan P. Podsakoff. 2003. "Common Method Biases in Behavioral Research: A Critical Review of the Literature and Recommended Remedies." Journal of Applied Psychology 88(5): 879-903.

Schwab, Donald P. 2005. Research Methods for Organizational Studies. Mahwah, NJ: Lawrence Erlbaum Associates.

Simler, Norman J. 1962. "Economics of Featherbedding." Industrial and Labor Relations Review 16(1): 111-21.

Simon, Herbert A. 1951. “A Formal Theory of the Employment Relationship.” Econometrica 19(3): $293-305$.

. 1973. “Applying Information Technology to Organization Design." Public Administration Review 33(3): $268-78$.

Slichter, Sumner H. 1941. Union Policies and Industrial Management. Washington, DC: Brookings.

, James Joseph Healy, and E. Robert Livernash. 1960. The Impact of Collective Bargaining on Management. Washington, DC: Brookings.

Storey, John. 2007. "Human Resource Management Today: An Assessment." In Human Resource Management: A Critical Text, edited by John Storey, pp. 3-20. London: Thomson Learning.

Webb, Sidney, and Beatrice Potter Webb. 1897. Industrial Democracy. New York: Longmans, Green \& Co.

Weinstein, Paul A. 1964. "The Featherbedding Problem." American Economic Review 54: 145-52.

Welbourne, Theresa M., and Alice O. Andrews. 1996. "Predicting the Performance of Initial Public Offerings: Should Human Resource Management Be in the Equation?" Academy of Management Journal 39(4): 891-919.

Willman, Paul. 1986. Technological Change, Collective Bargaining, and Industrial Efficiency. New York: Clarendon.

Wooldridge, Jeffrey M. 2010. Econometric Analysis of Cross-Section and Panel Data. Cambridge, MA: MIT. 